\title{
Mechanical Properties of Alumina-Mullite Whisker Composites
}

\author{
Nobuyuki TAMARI, Isao KONDOH, Takahiro TANAKA and Hiroaki KATSUKI* \\ Government Industrial Research Institute, Osaka, 1-8-31, Midorigaoka, Ikeda-shi, Osaka 563 \\ *Saga Ceramics Research Laboratory, 3100-5, Arita-cho, Nishimatsuura-gun, Saga 844
玉利信幸。近藤 功・田中隆裕・勝木宏昭*
大阪工業技術試験所, 563 池田市緑丘 1-8-31
*佐賀県割業技術センター, 844 佐賀県西松浦郡有田町 3100-5 \\ アルミナームライトウイスカー複合体の機械的性質
}

[Received October 12, 1992; Accepted March 16, 1993]

\begin{abstract}
Composite alumina ceramics with a mullite whisker content of up to $30 \mathrm{vol} \%$ were fabricated by hot-pressing at 1400 to $1600^{\circ} \mathrm{C}$ under $30 \mathrm{MPa}$ for $30 \mathrm{~min}$. The bending strength, hardness, elastic modulus and frac ture toughness of the hot-pressed bodies were investigated. Considerably dense alumina-mullite whisker composite ceramics were obtained by sintering at $1600^{\circ} \mathrm{C}$ with a whisker content of up to $30 \mathrm{vol} \%$. The composite with a whisker content of 10 vol\% and sin. tered at $1600^{\circ} \mathrm{C}$ exhibited the highest room temperature bending strength of around $750 \mathrm{MPa}$. This value is still lower than the maximum strength of alumina ceramic which is about $850 \mathrm{MP}$. However, the composites exhibited greater high temperature strength and hardness than alumina. The elastic modulus decreased with an increase in whisker content. No improvement was observed in the fracture toughness of the alumina by the addition of mullite whiskers, as very little crack deflection by the whiskers and pull-out of the whiskers occurred in these composites.
\end{abstract}

Krey-uorols : Alumina, Mullite whiskers, Composite ceramics, Sintering, Mechanical properties

\section{Introduction}

Recently, whisker-reinforced composite technology has been developed not only to improve the strength and toughness of ceramics but also to overcome brittleness, a major problem in engineering ceramics. Improvements in strength and toughness have been realized in alumina composites mixed with silicon carbide whiskers, and various applications, such as use in cutting tools, have been studied.1)-8) We have previously reported ${ }^{9), 10)}$ that replacing silicon carbide whiskers with silicon nitride whiskers makes it possible to produce dense composites at relatively low sintering temperatures of around $1600^{\circ} \mathrm{C}$, improving the fracture toughness by around $50 \%$ and the high temperature strength by three times for a composite with a whisker content of $30 \mathrm{vol} \%$.

This report deals with a study on the effects of sintering temperature and whisker content on the densification of alumina-mullite whisker composites, and on the bending strength, Vickers hardness, elas- tic modulus and fracture toughness.

\section{Experimental}

Alumina powder (Taimei Chemical Co., TAIMICRON-TM-D) with an average grain size of $0.22 \mu \mathrm{m}$ was used and Kaolin-derived mullite whiskers comprised of $71.2 \mathrm{wt} \% \mathrm{Al}_{2} \mathrm{O}_{3}$ were used for reinforcement. ${ }^{11), 12)}$ A scanning electron micrograph of the mullite whiskers used is shown in Fig. 1. The whiskers are approximately $1 \mu \mathrm{m}$ in diameter and $5 \mu \mathrm{m}$ in length. These starting powders were ball-milled in distilled water for $24 \mathrm{~h}$. The mixture was dried, and then screened through a 16-mesh sieve (opening size: $1 \mathrm{~mm}$ ). The mullite whiskers were added the alumina powder to make three different mixed powders with whisker contents of 10,20 , or $30 \mathrm{vol} \%$.

Sintering was carried out by the hot-pressing method. The mixed source materials were placed in a graphite mold, and after applying the given pressure, the temperature was increased to the required level at a rising speed of around $70^{\circ} \mathrm{C} / \mathrm{min}$. After a given time, the pressure was released and the materials were left to cool. Sintering conditions during the pressurized period were $1400-1600^{\circ} \mathrm{C}, 30 \mathrm{MPa}$, and $30 \mathrm{~min}$. Plates of about $20 \times 40 \times 5 \mathrm{~mm}$ were obtained by this process.

The sintered samples were ground by a \#200 diamond wheel, and their bulk densities were measured

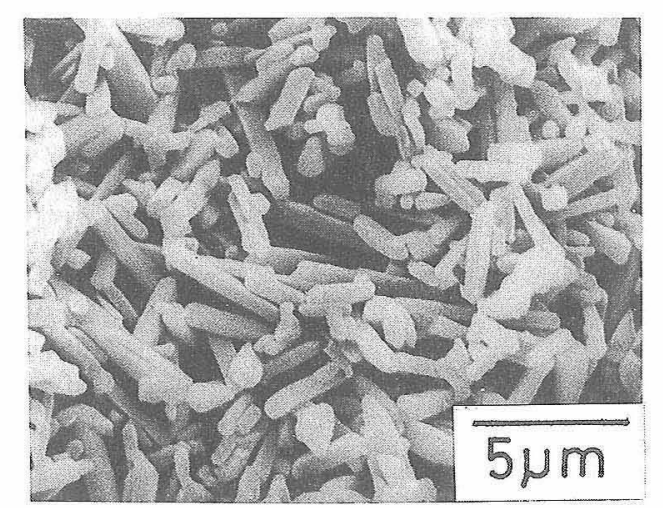

Fig. 1. Scanning electron micrograph of mullite whiskers used. 
by the Archimedean method.

Test pieces with cross sections of $3 \times 4 \mathrm{~mm}$ were prepared for strength testing, with the tension sides finished by a \#800 diamond grind plate. The strength of the pieces was tested by the three-point bending method under the conditions of a $30 \mathrm{~mm}$ span and a $0.5 \mathrm{~mm} / \mathrm{min}$ loading rate. The high-temperature test was carried out after the specimen had been kept at a specified temperature for $10 \mathrm{~min}$ in air.

Hardness was measured by a Vickers-type hardness tester under the conditions of $98 \mathrm{~N}$ and $30 \mathrm{~s}$. The elastic modulus was measured by the bending resonance method on a $1 \times 5 \times 40 \mathrm{~mm}$ specimen in accordance with the JIS R 1602.

Fracture toughness was tested by the SEPB method and the IF method in accordance with the JIS R 1607. In the former method, a three-point bending test with a $30 \mathrm{~mm}$ span and a loading rate of $0.5 \mathrm{~mm} / \mathrm{min}$ was conducted on a $4 \times 3 \mathrm{~mm}$ square precracked specimen, while for the latter, the test was conducted on a specimen polished with $1 \mu \mathrm{m}$ diamond pastes to give it a mirror finish, and with the conditions of $98 \mathrm{~N}$ and $30 \mathrm{~s}$.

\section{Results and discussion}

Figure 2 shows the effects of the sintering temperatures and the whisker contents on the densification of the composites. Here the value of the relative density is shown by the ratio of the bulk density against the theoretical density of a simple mixture of alumina and mullite. At $1400^{\circ} \mathrm{C}$, the relative density decreased monotonously as the whisker content increased. Although only the composite with a whisker content of $10 \mathrm{vol} \%$ densified at $1500^{\circ} \mathrm{C}$, considerably dense composites were obtained with whisker contents of up to $30 \mathrm{vol} \%$ at $1600^{\circ} \mathrm{C}$.

Figure 3 shows the bending strengths of the specimens used for Fig. 2 at room temperature. At a sintering temperature of $1400^{\circ} \mathrm{C}$, the strength decreased steadily along with the increase in whisker content, due to the decrease in density. At $1500^{\circ} \mathrm{C}$ and $1600^{\circ} \mathrm{C}$, the maximum strength value was obtained by a whisker content of 10 vol\%. The composite sintered at $1600^{\circ} \mathrm{C}$, in particular, exhibited the highest strength value of around $750 \mathrm{MPa}$. However, the value fell short of $850 \mathrm{MPa}$, the maximum strength of an alumina ceramic sintered at $1400^{\circ} \mathrm{C}$. A similar result was observed for aluminasilicon nitride whisker composites. ${ }^{9), 10)}$

Figure 4 indicates the bending strength at high temperatures of the composites sintered at $1600^{\circ} \mathrm{C}$. Here, we included in the figure the strength of the alumina sintered at $1400^{\circ} \mathrm{C}$ for comparison. The bending strength of the alumina decreased as the test temperature increased. The strength of alumina sintered at $1400^{\circ} \mathrm{C}$ decreased significantly to about $50 \%$ at $1000^{\circ} \mathrm{C}$, about $33 \%$ at $1200^{\circ} \mathrm{C}$, and about $24 \%$ at $1300^{\circ} \mathrm{C}$, of its strength at room temperature. In contrast, although the strengths of all the compo- sites also decreased with increasing testing temperature, their values were higher than those of the alumina at every temperature tested. At a testing temperature of $1300^{\circ} \mathrm{C}$, the composite with a whisker content of $20 \mathrm{vol} \%$, in particular, retained about $50 \%$ of its strength at room temperature. Thus the small decrease in the high temperature strength of the composite is considered to be caused by the decrease in SCG (subcritical crack growth), as slippage at the grain boundary, cavity growth and cavity linkage are inhibited. This is also thought to be the cause for the decreased alumina strength at high temperature, as

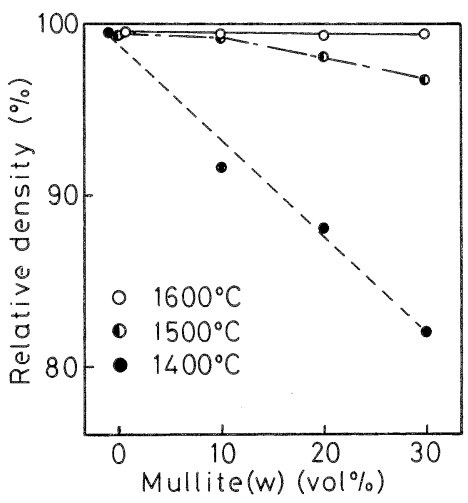

Fig. 2. Effects of sintering temperature and whisker content on the densification of alumina-mullite whiker composite.

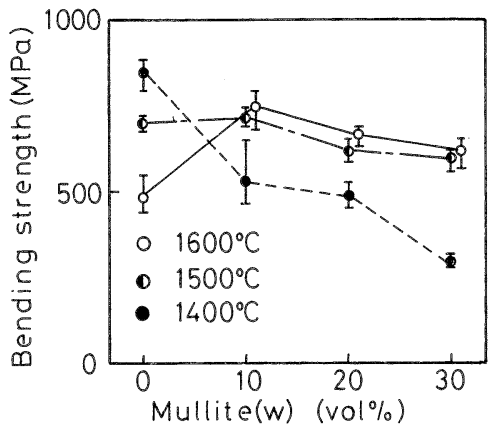

Fig. 3. Effects of sintering temperature and whisker content on the room temperature bending strength of alumina-mullite whisker composite.

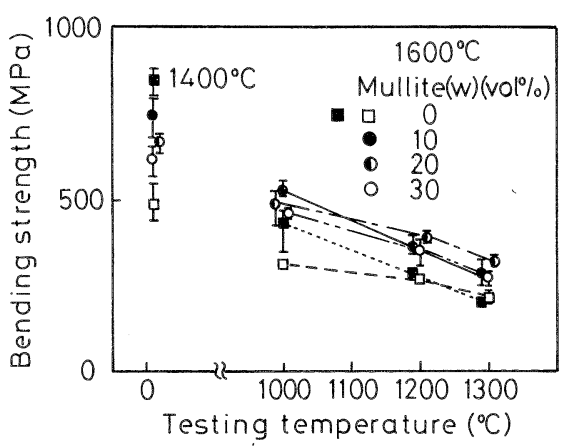

Fig. 4. High temperature bending strength of monolithic alumina and alumina-mullite whisker composite. 
has been pointed out for alumina-silicon carbide powder composites by Niihara et al. ${ }^{13)}$

Figure 5 indicates the effect of whisker content on the Vickers hardness and elastic modulus of the composites sintered at $1600^{\circ} \mathrm{C}$. The hardness increased as the whisker content increased, and was as high as $16.2 \mathrm{GPa}$ at $30 \mathrm{vol} \%$. The value was less than the value for the monolithic alumina sintered at $1400^{\circ} \mathrm{C}$ $(17.1 \mathrm{GPa})$, as the same can be said for the strength at room temperature. The elastic modulus, on the other hand, decreased as the whisker content increased, due to the smaller elastic modulus of mullite compared to that of alumina (mullite : $215 \mathrm{GPa}$, alumina : $385 \mathrm{GPa}$ ).

Figure 6 shows the effect of whisker content on the fracture toughness of the composites sintered at $1600^{\circ} \mathrm{C}$. The monolithic alumina possessed a fracture toughness of $3.5 \mathrm{MPa} \cdot \mathrm{m}^{1 / 2}$ determined by the SEPB method and $3.1 \mathrm{MPa} \cdot \mathrm{m}^{1 / 2}$ determined by the $\mathrm{IF}$ method. Increasing the whisker content decreased fracture toughness to $2.3 \mathrm{MPa} \cdot \mathrm{m}^{1 / 2}$ by the SEPB method for a whisker content of 30 vol\%. On the other hand, the fracture toughness determined by the IF method showed a certain value of around 3 $\mathrm{MPa} \cdot \mathrm{m}^{1 / 2}$, regardless of the whisker content. These results suggest that the incorporation of mullite

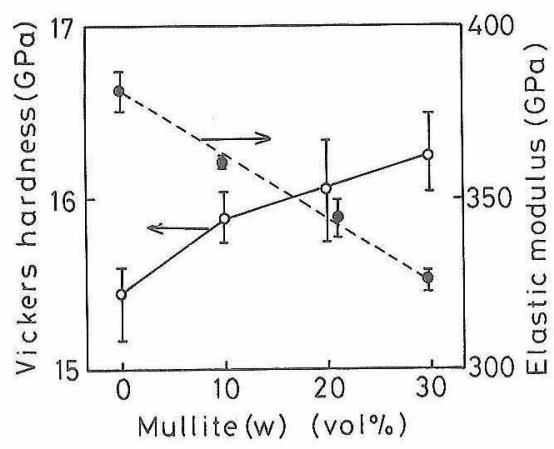

Fig. 5. Effect of whisker content on the Vickers hardness and elastic modulus.

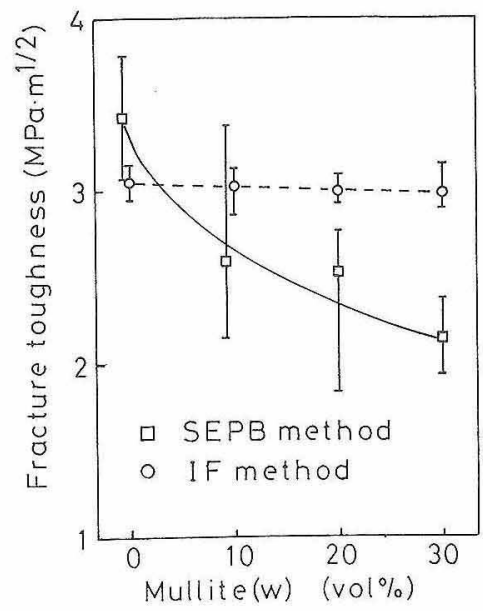

Fig. 6. Effect of whisker content on the fracture toughness. whiskers does not contribute to an improvement in the fracture toughness of alumina ceramics.

Figure 7 shows the status of crack propagation from the corners of Vickers indentation in alumina and in a $20 \mathrm{vol} \%$ whisker composite. In both cases, cracks tended to deflect but more for the alumina than for the composite. Figure 8 shows the fractured

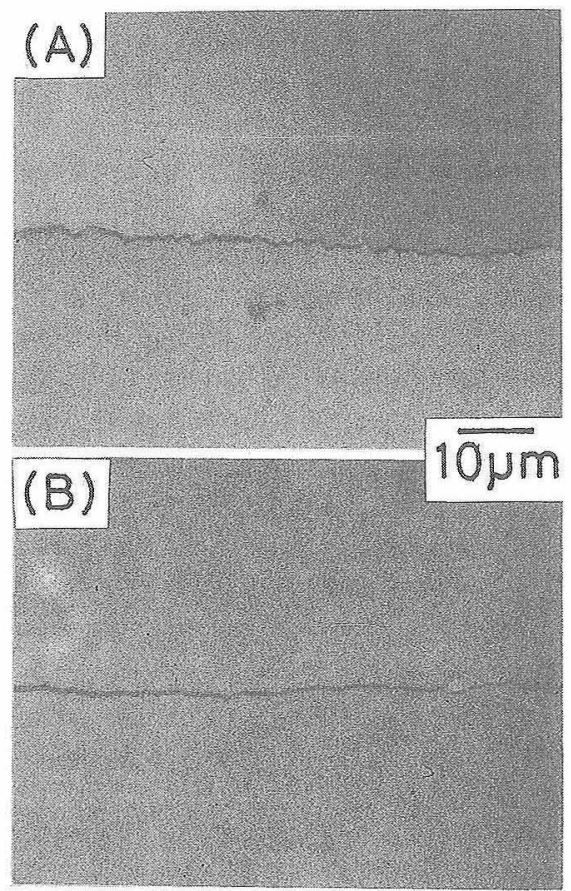

Fig. 7. Crack propagation from the corner of Vickers indentation in monolithic alumina $(A)$, and alumina-mullite whisker composite with $20 \mathrm{vol} \%$ whiskers (B).

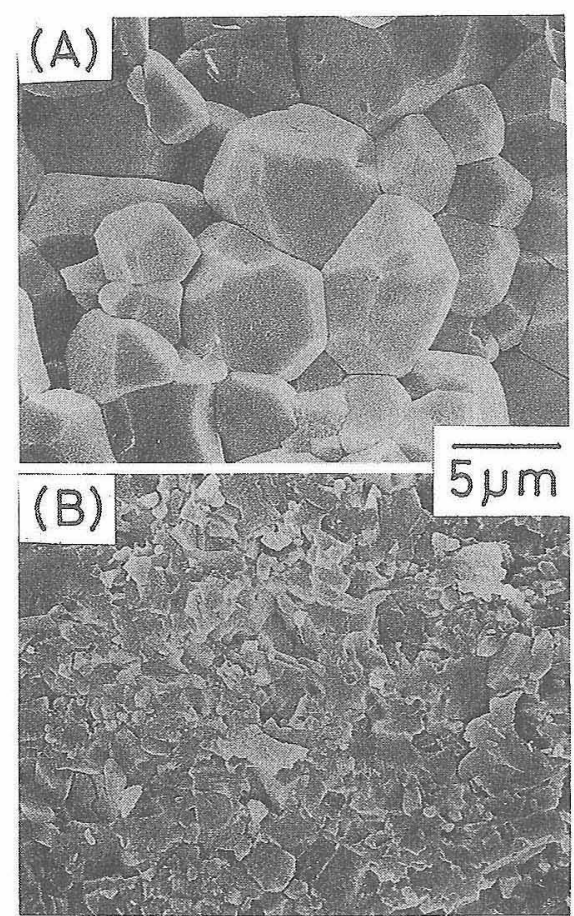

Fig. 8. Fractured surfaces of monolithic alumina (A), and alumina-mullite whisker composite with 20 vol\% whiskers (B). 
surfaces of the alumina and the composite with a whisker content of $20 \mathrm{vol} \%$ sintered at $1600^{\circ} \mathrm{C}$. As observed in the alumina-silicon nitride whisker composites, ${ }^{9), 10)}$ monolithic alumina fractured at the boundary of alumina grains, while the dense whisker composite fractured through the alumina grains. In these composites, the whiskers are fractured at the fracture plane of the matrix, and little pull-out of the mullite whiskers was observed because of strong bonding between the mullite whiskers and the alumina matrix or the shorter length of the mullite whiskers used.

As mentioned above, it was found to be difficult to improve the fracture toughness of alumina ceramics by the addition of mullite whiskers, as minimal crack deflection by the whiskers and pull-out of the whiskers occurred, and due to the decrease in the elastic modulus. However, further studies on other composite ceramics consisting of oxide whiskers and oxide matrices are necessary, as oxidation can be neglected in the oxide composites.

\section{References}

1) G. C. Wei and P. F. Becher, Am. Ceram. Soc. Bull., 64, 298304 (1985).

2) J. Homeny, W. L. Vauchn and M. K. Ferber, Am. Ceram. Soc. Bull., 66, 333-38 (1987).

3) M. Karpman and J. Clark, Composites, 18, 121-24 (1987).

4) T. Yamamoto, M. Asano, K. Ueno and N. Tamari, J. Japan Soc. Powder and Powder Metall., 36, 859-64 (1989).

5) S. Itoh, M. Watanabe, M. Matsubara and Y. Matsuo, J. Am. Ceram. Soc., 72, 1880-84 (1989).

6) P. F. Becher, P. Angelini, W. H. Warwick and T. N. Tiegs, J. Am. Ceram. Soc., 73, 91-96 (1990).

7) J. Homeny and W. L. Vaughn, J. Am. Ceram. Soc., 73, 394$402(1990)$.

8) P. H. McCluskey, R. K. Williams, R. S. Graves and T. N. Tiegs, J. Am. Ceram. Soc., 73, 461-64 (1990).

9) I. Kondoh, M. Asahina and N. Tamari, Seramikkusu Ronbunshi, 97, 1424-27 (1989).

10) N. Tamari, T. Tanaka, I. Kondoh and S. Kose, Seramikkusu Ronbunshi, 99, 370-75 (1991).

11) H. Katsuki, S. Furuta, H. Ichinose and H. Nakano, Seramikkusu Ronbunshi, 96, 1081-86 (1988).

12) H. Katsuki, A. Kawahara, H. Ichinose, S. Furuta and S. Yoshida, Seramikkusu Ronbunshi, 97, 1521-24 (1989).

13) K. Niihara, A. Nakahira, T. Uchiyama and T. Hirai, "Fracture Mechanics of Ceramics 7", Plenum Press (1986) pp. 103-16. 